\title{
Hypoalbuminemia in hemodialyzed end stage renal disease patients: risk factors and relationships - a 2 year single center study
}

Nagaraja Rao Sridhar ${ }^{* *}$ and Sowmya Josyula ${ }^{2}$

\begin{abstract}
Background: Malnutrition affects 1/3 of hemodialysis patients and associates with a higher risk of morbidity and mortality. Serum albumin is a marker of nutrition and inflammation, and predicts mortality, particularly when $<3.8 \mathrm{~g} / \mathrm{dL}$. This study was performed to identify risk factors for hypoalbuminemia $(<3.8 \mathrm{~g} / \mathrm{dL})$ and the particular temporal relationship and strength of association between protein intake (nPCR) and serum albumin when confounding variables are taken into account.
\end{abstract}

Methods: Demographic, clinical, and dialysis-related data of 57 ESRD patients on hemodialysis over 24 months in 6 temporal segments were analyzed with serum albumin as a continuous, and categorical outcome (with $3.8 \mathrm{~g} / \mathrm{dl}$ as cut-off) variable, against 13 potential independent variables [4 demographic factors, 3 nutrition-related, and 5 morbidity-related parameters, and \% urea reduction ratio (URR)]. The temporal relationships between albumin and $n P C R$ were analyzed for the concurrent \& 3 subsequent months in each temporal segment.

Results: The impact of $n P C R$ on serum albumin $(p<0.05)$ was significant but with no discernible temporal relationship. Advancing age, longer vintage, female gender, diabetes mellitus, $\mathrm{nPCR}$, serum phosphate and ferritin had significant correlation with albumin $<3.8 \mathrm{~g} / \mathrm{dl}(\mathrm{p}<0.05)$. Serum phosphate levels correlated positively, and fever, bacteremia, hospital stay and weight loss negatively, with mean serum albumin but did not negate the effect of $\mathrm{nPCR}$. Regression analysis showed that mean albumin associated with $\mathrm{nPCR}$, fever, hospital stay, bacteremia, dialysis vintage, age, sex, and diabetes mellitus; and that an albumin level of $<3.8 \mathrm{~g} / \mathrm{dl}$ associated with age, female sex, diabetes, lower nPCR, and higher ferritin.

Conclusion: Suggested target albumin levels were not met in elderly, female, and diabetic patients. The association of $\mathrm{nPCR}$ with albumin was not nullified by confounding demographic or morbidity-related factors. nPCR had no demonstrable temporal relationship with albumin.

\section{Background}

370,274 U.S residents received maintenance hemodialysis in 2009 [1]. The expected life span is $20-25$ years shorter for dialyzed patients than for age, sex, and race - matched U.S. controls over 45 years of age [2]. Protein-energy malnutrition is a major risk factor for mortality and inflammation; the presence of co-morbid conditions like cardiovascular disease increases this risk further [3-7].

\footnotetext{
* Correspondence: nsridhar@buffalomedicalgroup.com

'Department of Internal Medicine (Nephrology), Buffalo General Hospital, University at Buffalo, and Buffalo Medical Group, 85 High Street, Buffalo, New York, USA

Full list of author information is available at the end of the article
}

Serum albumin is a marker of nutrition and inflammation and predicts mortality [8-10]. Studies have suggested that a serum albumin level of less than $3.8 \mathrm{~g} / \mathrm{dL}$ (and/or a reduction in serum albumin levels) confers a greater mortality risk in patients with end-stage renal disease (ESRD) [11,12] and in various other disease states [13]. Guidelines proposed by the Centers for Medicare and Medicaid Services (CMS), Dialysis Outcomes Quality Initiative (DOQI) and the International Society of Nutrition Managers to maintain target serum albumin levels in ESRD are $>/=3.5,4.0$, and $3.8 \mathrm{~g} / \mathrm{dl}$ respectively $[10,14,15]$. Serum albumin levels are considered indicators of quality of care at some dialysis facilities and may be included as a parameter of quality by the Centers for

\section{Biomed Central}


Medicare and Medicaid Services (CMS) in the future. A large study of intra-dialytic parenteral nutrition (IDPN) did not show a mortality benefit vis-à-vis oral supplements [16]. In the present retrospective study, we tried to identify factors associated with serum albumin and identify risk factors for hypoalbuminemia $(<3.8 \mathrm{~g} / \mathrm{dL})$ using only demographic and those biochemical measurements that are routinely available in the United States; we were particularly interested in the temporal association between nPCR (normalized protein catabolic rate) as an indicator of protein intake and serum albumin over an extended period of 24 consecutive months. Further, we tried to understand whether this relationship between nPCR and albumin was robust when the confounding effects of other factors that appeared to correlate with albumin levels in univariate analyses were taken into account.

\section{Methods}

The current study was undertaken at a single tertiarycare hospital-based outpatient hemodialysis center with about 100 patients during the study period of which regular, uninterrupted, serum albumin levels and 10 other numerical variables were available for 57 patients for 24 consecutive months (the remaining patients were transferred to free-standing centers within a few months, died, or received transplants) who gave signed informed consent to have their data included in the study which was approved by the University at Buffalo's Institutional Review Board. The inclusion criteria included patients who were on maintenance hemodialysis from February 2008 to February 2010 and their ability to sign an informed consent. Hemodialysis was performed three times weekly in 55 patients and twice weekly in 2 patients. Low flux dialyzers using modified cellulosic membranes were used in all the patients. There were no major changes made in the dialysis prescription during the two year period except those pertaining to target weight, heparin, and dialysate potassium concentration.

All patients had been advised to restrict total dietary phosphate to between 1000 and $1500 \mathrm{mg}$ per day. Food diaries were not available for review.

A total of 10 patients had been dialyzed at this tertiary hospital-based outpatient dialysis facility for longer than 4 months but less than 24 months and were not included.

The outcome variable, serum albumin, was measured by the bromocresol purple method which gives slightly lower values than the bromocresol green method. Therefore a value of $3.8 \mathrm{~g} / \mathrm{dl}$ which is $0.2 \mathrm{~g} / \mathrm{dl}$ lower than that suggested by K/DOQI was used for analysis; this is $0.3 \mathrm{~g} / \mathrm{dl}$ higher than the target suggested by CMS. Age, dialysis vintage in months, nPCR, serum phosphate, \% dry weight change, body temperature before, during, and at closure of $\mathrm{HD}$ to enumerate the number of febrile episodes if $>37$ degrees $\mathrm{C}$, the number of episodes of bacteremia, the number of days spent at any hospital when the outpatient status of the patient was suspended, and the \% URR were used as continuous independent variables. Patient-gender and diabetes mellitus were used as categorical independent variables. All the laboratory measurements were made by standard assay methods at the clinical laboratories of Kaleida Health. Dialysis vintage was counted as months from the commencement of any form of dialysis. All numerical data were expressed in unaltered form over the 2 years and as cross-sectional means for evaluation of temporal relationships within each 4-month period over the 2 years ( 58 variables $\times 57$ patients $\times 24$ months).

\section{Statistical analysis}

The analysis was done using PASW/18 (2009 SPSS Inc.) and the variables expressed as means $\pm \mathrm{SD}$. $\mathrm{p}<0.05$ was considered to be significant. The relationship between serum albumin as a continuous (scaled) variable and each of the independent numerical variables was studied using the Pearson Correlation Coefficient; the strength of this association was then tested using multiple regression including other covariates and the attributable impact of each independent variable on mean serum albumin levels was calculated as the coefficient beta (standardized for the varied units used to measure the 11 non-demographic variables) with $95 \%$ confidence intervals (CI). A $2 \times 2$ table was used to study the impact of gender and diabetes mellitus on the number of instances of albumin $<3.8 \mathrm{~g} / \mathrm{dl}$ by calculating the likelihood ratio using Chi-square tests with continuity correction. Binary Logistic Regression (BLR) was used for multi variable relationships with serum albumin levels of $<3.8 \mathrm{~g} / \mathrm{dl}$ as the categorical outcome variable and the likelihood ratio of each independent variable (exponent B) derived with 95\% CI; the significance of the results was calculated with and without bootstrapping of 1000 sample iterations across variables in an effort to make the analysis robust. Temporal relationships between serum albumin and nPCR (as a measure of protein intake) and serum ferritin (which correlates negatively with serum albumin) were studied using Pearson's correlation with data submitted to analysis as continuous and 4-monthly cross-sectional means respectively; the 24 month period was divided into 6 blocks of 4 months each because serum ferritin was measured only once every 4 months by unit policy necessitated by CMS reimbursement. Erythrocyte sedimentation rates and C-reactive protein levels were not routinely available for the 57 patients over the 24 months studied, again determined by standard reimbursement related policies. The specific impact of a given month's mean nPCR on the mean serum albumin levels of the concurrent and 3 subsequent months was expressed as the F statistic with 3 degrees of freedom for 4 methods of 
statistical analysis: Pillai's trace, Wilk's lambda, Hoteling's trace and Roy's largest root. Finally, multinomial regression was used to study the impact of each factor shown to be significant by Pearson correlation on a range of outcome albumin levels to double check the impact of nPCR, the independent variable of interest, at each cut-off point of albumin from 1.9 through $4.1 \mathrm{~g} / \mathrm{dl}$.

\section{Results}

Of the 57 patients 26 were male and 31 were female. The median age was 57 years (range 29 to 85 years) and the mean 58 years. The causes of renal failure included the following: diabetic nephropathy $(\mathrm{n}=27)$, primary hypertensive renal disease $(\mathrm{n}=17)$, chronic glomerulonephritis $(n=9)$, unknown etiology $(n=7)$ and obstructive pyelonephritis $(\mathrm{n}=1)$.

The mean values of the clinical and dialysis data, serum biochemistry results, and potential contributors to hypoalbuminemia of 57 patients are given in Table 1.

\section{Univariate analysis}

An inverse correlation was found between age and mean serum albumin $(\mathrm{p}<0.001)$. Advancing age associated with lower albumin (especially in women (Figure 1) and in both diabetics and non-diabetics (Figure 2) except in the 9 th decade in which there were only 5 diabetics who had a higher mean albumin level than their 18 nondiabetic counterparts among our patients, mainly due to the values of 2 patients. Of the continuous variables nPCR (Figure 3), \% change in post-HD goal (dry) weight,

Table $\mathbf{1}$ Clinical, dialysis and laboratory data in $\mathbf{5 7}$ hemodialysis patients and co-morbid features predisposing to hypoalbuminemia

\begin{tabular}{ll}
\hline Parameter & Mean \pm SD \\
\hline Age (yrs) & $57.9 \pm 14.6$ \\
Dialysis vintage (mo) & $47.8 \pm 38.6$ \\
BMI (kg/sq.m) & $30.2 \pm 10.9$ \\
Albumin(g/dl) & $3.38 \pm 0.40$ \\
Ferritin (ng/ml) & $623.57 \pm 356.04$ \\
nPCR & $1.01 \pm 0.33$ \\
Phosphate (mg/dl) & $5.69 \pm 1.91$ \\
URR\% & $73.96 \pm 19.99$ \\
WBC (1000/cmm) & $6.72 \pm 2.32$ \\
Comorbid Features & $n$ \\
Catheter use (6-24 months) & 18 \\
Coronary disease & 12 \\
Peripheral vascular disease & 08 \\
CHF (systolic +/- diastolic) & 10 \\
CHF (diastolic alone) & 06 \\
Malignancy & 05 \\
\hline
\end{tabular}

serum phosphate were positively correlated with mean serum albumin levels $(\mathrm{p}<0.001$ for all $)$ whereas the number of episodes of bacteremia $(\mathrm{p}<0.001)$, febrile episodes, and days spent in hospital $(\mathrm{p}<0.05$ for both) showed a negative correlation with mean albumin levels. Dialysis vintage, \% URR, and ferritin did not show a correlation with mean albumin (Table 2). Female and diabetic patients were more likely to have a serum albumin $<3.8 \mathrm{~g} / \mathrm{dl}$ (Table 3).

\section{Multivariate analysis}

Multiple linear regression (Table 4) showed that mean serum albumin as the outcome variable was most significantly impacted by age, diabetes mellitus, hospital stay, and bacteremia $(\mathrm{p}</=0.005)$; and to a smaller degree of significance by gender, vintage, and nPCR $(\mathrm{p}<0.05$ for each). Binary logistic regression (BLR) showed that advanced age, female sex, and diabetes mellitus conferred the greatest hazard of a serum albumin $<3.8 \mathrm{~g} / \mathrm{dl} \quad(\mathrm{p}</=0.008)$ followed by $\mathrm{nPCR}$, dialysis vintage, and ferritin $(\mathrm{p}<0.05)$. Serum phosphate and $\%$ URR did not appear to impact either the mean or the target albumin levels by BLR (Table 5).

The albumin levels of any 4 consecutive months did not significantly differ from each other or the index month by ANOVA. The effect of nPCR of the index month on mean albumin in any of the four subsequent months was not significantly different than on that of the index month: the exact statistic (F) for albumin being 0.572 for each of the 4 months in any temporal segment $(\mathrm{p}=0.63)$ and the within-subjects-design (intercept) against nPCR of month 0 (index month) for each segment was $0.641(\mathrm{p}=0.58)$. Thus we were not able to demonstrate any longitudinal pattern of variation in the albumin levels relative to nPCR of any given month.

Multinomial regression demonstrated the impact of $\mathrm{nPCR}$ at each level of increment of albumin of $0.1 \mathrm{~g} / \mathrm{dl}$ from 1.9 to $4.1 \mathrm{~g} / \mathrm{dl}$ when fever, days in hospital, bacteremia, and dry weight change, age (decile), sex, phosphorus, and WBC counts, the factors shown by Pearson correlation to be significant or nearly significant, were taken into account $(\mathrm{p}<0.001)$.

\section{Discussion}

This retrospective analysis suggests that the suggested serum albumin targets were not met in the elderly and diabetic patients, particularly women and that there was a significant association between mean albumin and nPCR (protein intake) which was not nullified by confounding non-nutritional factors. Such hypoalbuminemia is known to unfavorably alter prognosis [17-20].

Recent publications have confirmed an association of serum albumin and mortality though some have questioned its value as a nutritional marker $[11,12,15,21]$ 


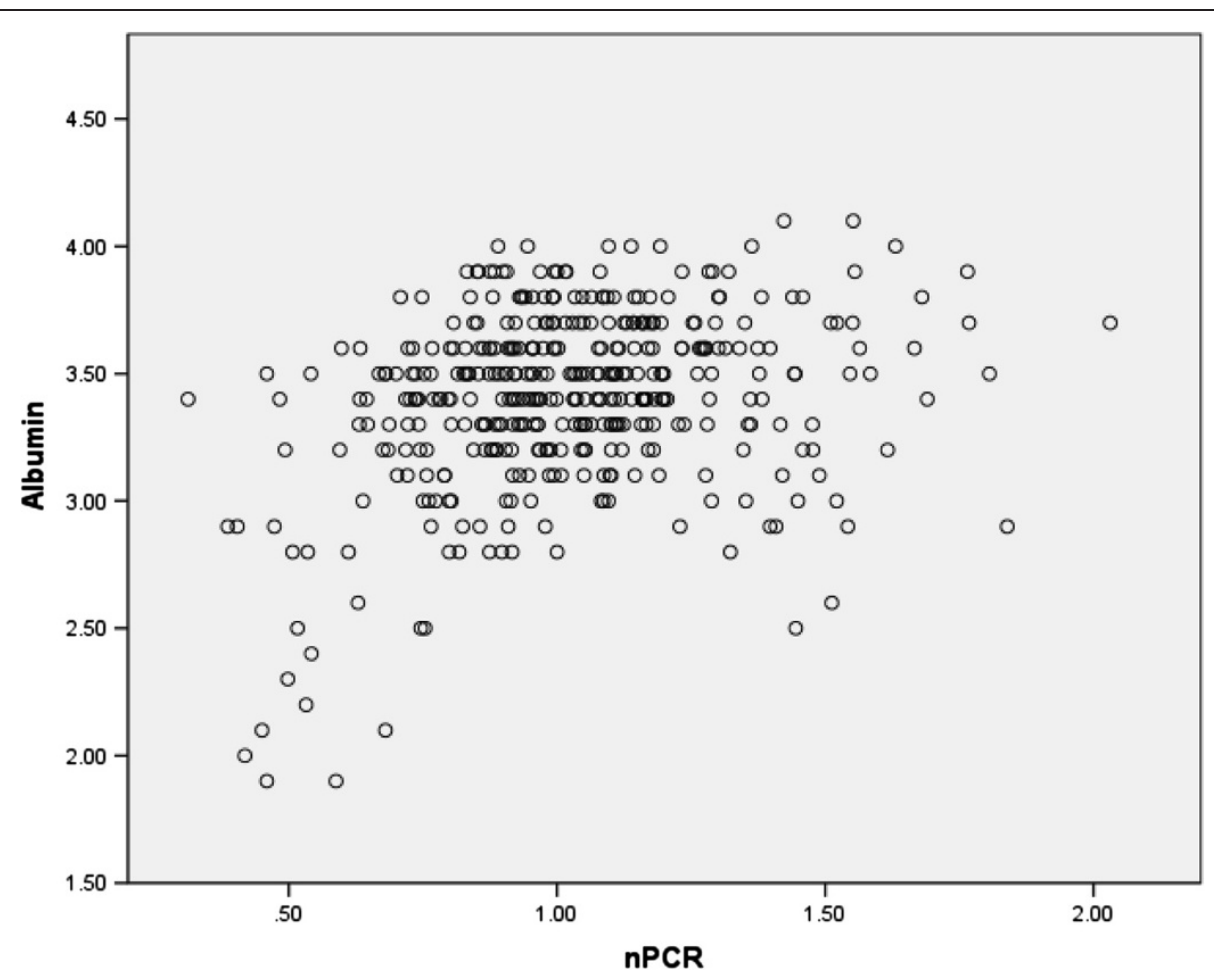

Figure 1 Serum albumin by gender and decile of age.

\section{Mean serum albumin by decile of age and and gender}

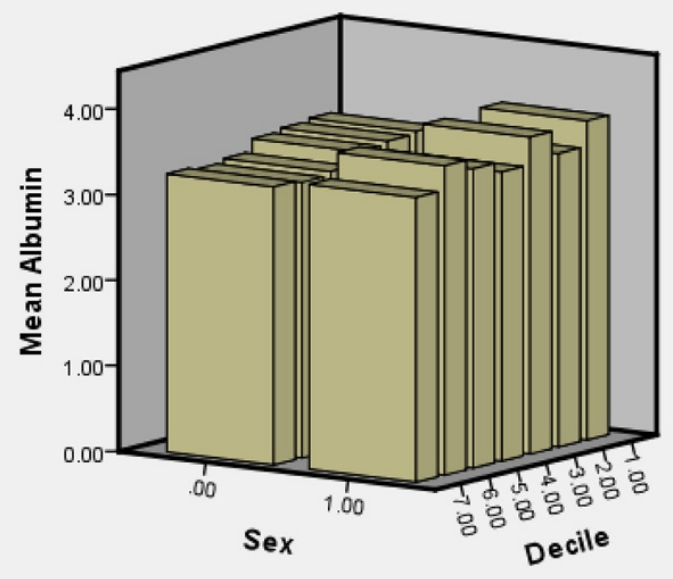

$0=$ Female $; 1=$ Male

Figure 2 Serum albumin by age decile and diabetic status. 


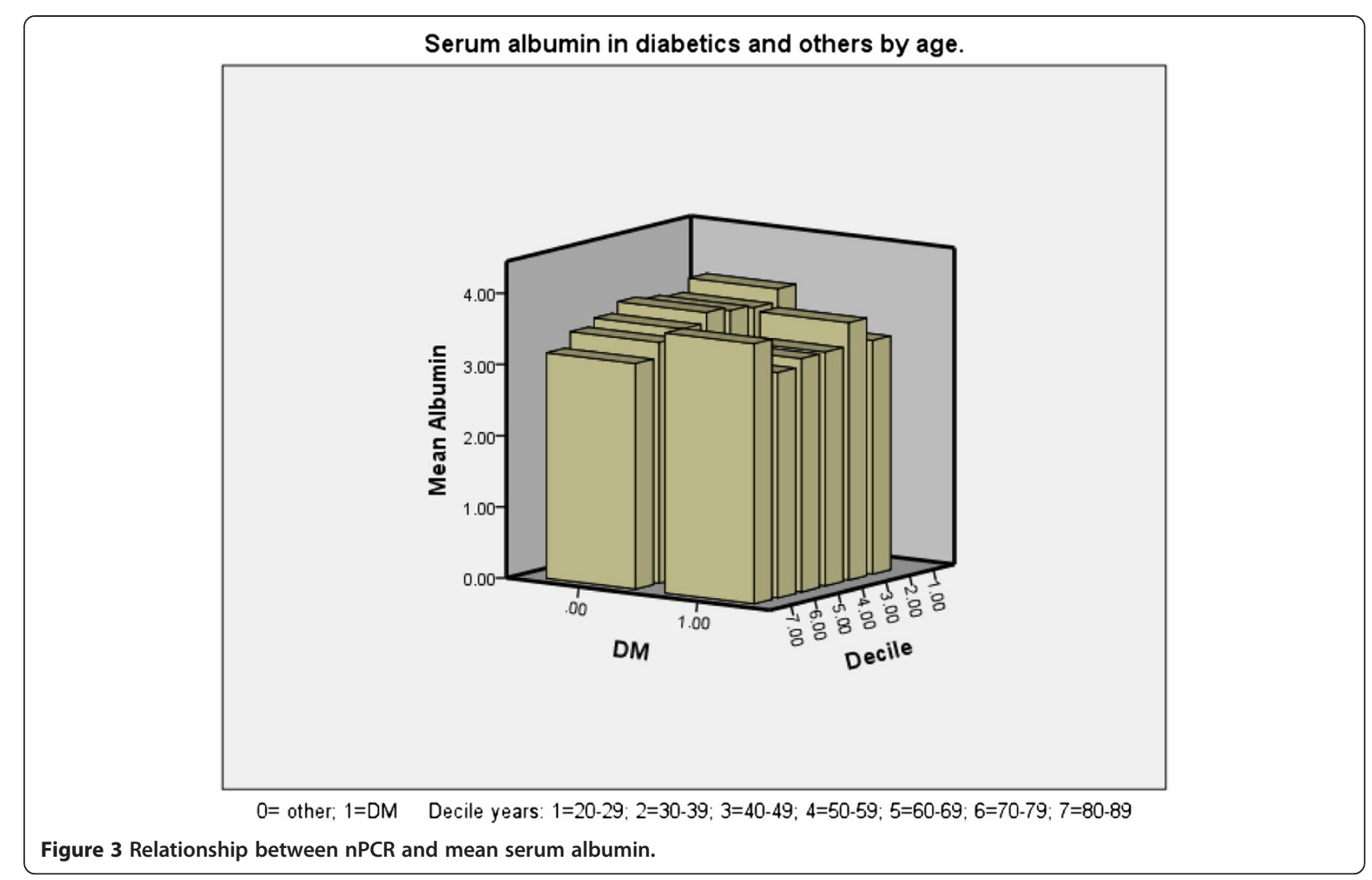

because acute illnesses, especially inflammation, appear to be associated with a reduction in its levels, most likely due to catabolism [22]. Hypoalbuminemia is associated with hypotension [23], progressive left ventricular dysfunction [24] and reduced intra-dialytic skin blood flow [25] and is due to decreased synthesis; attempts to correct hypoalbuminemia have not resulted in improved mortality so far [26-37].

Table 2 Correlation between mean 4 monthly serum albumin and risk factors

\begin{tabular}{lcc}
\hline & Pearson coefficient & $\boldsymbol{p}$ \\
\hline Age in years & -0.25 & $<0.001$ \\
Vintage in months & 0.05 & 0.35 \\
nPCR & 0.31 & $<0.001$ \\
\% Goal Weight Change & 0.23 & $<0.001$ \\
Serum Phosphate (mg/dl) & 0.22 & $<0.001$ \\
\%URR & 0.03 & 0.55 \\
Episodes of fever & -0.11 & 0.02 \\
Leukocytes /cmm & -0.09 & 0.07 \\
Ferritin (ng/ml) & 0.02 & 0.64 \\
Bacteremia (episodes) & -0.27 & $<0.001$ \\
Days in hospital & -0.13 & 0.01 \\
\hline
\end{tabular}

$\mathrm{P}<0.05=$ significant.
Age, sex, catheter use, nPCR, creatinine, dialysis adequacy, WBC number, neutrophil:lymphocyte ratio, C-reactive protein, hemoglobin and aspartate aminotransferase(AST) level are associated with albumin levels in the serum [27-29]. Advanced age ( $>65$ years) is associated with lower serum albumin in large crosssectional studies [38,39]. We used age as a continuous and ordinal variable and found a correlation with hypoalbuminemia in both men and women (Tables 2). Reductions in dietary protein and energy intake appear to be the likely reasons for hypoalbuminemia in the elderly [40,41]. Our results confirm a direct, and somewhat robust association between protein intake (nPCR) and serum albumin similar to the results of others [42-45] . Investigators studying a small series of patients found a catabolic state when the dietary protein intake was $42.5 \mathrm{~g} / \mathrm{d}$ (nPCR, $0.78 \mathrm{~g} / \mathrm{kg} / \mathrm{d}$ ) and an anabolic state when the dietary protein intake was $73.5 \mathrm{~g} / \mathrm{d}$ (nPCR, $0.88 \mathrm{~g} / \mathrm{Kg} / \mathrm{d}$ ) in a prospective cross-over trial confirming an association between dietary protein intake and nPCR in hemodialyzed patients [46]; the MDRD study in preESRD patients showed similar results [47]. As described in the literature [48], advancing age, female sex, and the presence of diabetes were associated with a greater hazard of hypoalbuminemia in our patients. Unlike some investigators [49] we did not find a stronger relationship between albumin and indicators of inflammation (ferritin, 
Table $32 \times 2$ Table for risk of hypoalbuminemia by gender and diabetes

\begin{tabular}{llllr}
\hline & & Alb $>\mathbf{3 . 8} \mathbf{g} / \mathbf{d l}$ Instances (\%) & Alb <3.8 g/dl Instances (\%) & Total (\%) \\
\hline Gender $\left(^{*}\right)$ & Female & $13(7)$ & $173(93)$ & $186(100)$ \\
& Male & $35(22.4)$ & $121(77.6)$ & $156(100)$ \\
Diabetes(\#) & Present & $6(3.6)$ & $161(96.4)$ & $167(100)$ \\
& Absent & $42(24)$ & $133(76)$ & $175(100)$ \\
\hline
\end{tabular}

* Likelihood ratio (Chi-square with continuity correction) of instances of albumin $<3.8$ in female patients $=17.08$ (asymptotic $p<0.001$ )

\# Likelihood ratio (Chi-square with continuity correction) of instances of albumin $<3.8 \mathrm{~g} / \mathrm{dl}$ in diabetics $=27.8$ (asymptotic $p<0.001$ ).

WBC, fever) than between albumin and protein intake (nPCR) and serum phosphate. The relationship of albumin and nPCR remained highly significant after discounting the effect of phosphate levels in our group of patients using partial correlation $(\mathrm{p}<0.001)$ and multi-variable methods ( $\mathrm{p}=0.01$ ) consistent with the experience of other investigators [50]. Mortality is associated with lower serum albumin levels and nPCR in well dialyzed patients $[51,52]$ and dietary phosphate intake and dietary phosphate to protein ratio have been shown to have an adverse effect on mortality in a recent study [53]. Zitt et al. in a prospective cohort study (INVOR) found a higher risk of mortality when the albumin and phosphate were both low or high than when the phosphate levels were low and those of albumin high [54]. However, prescribed dietary phosphate restriction was associated with higher mortality when time-dependent confounders were included in a post hoc analysis of the Hemodialysis Study whose authors postulate that phosphate-rich foods tend to be nutrient dense and presumably protein-rich [55]. Serum phosphate levels may reflect this greater nutrient intake although adherence to phosphate binders and the degree of hyperparathyroidism would also impact them. A surprising lack of association was noticeable between serum albumin and small solute clearance as indicated by \% URR in our patients. We attribute this finding to our unit policy that dictated the use of dialyzers with higher urea clearance, increasing dialysis time and blood flow rates when $\mathrm{KT} / \mathrm{V}$ was $<1.4$ which resulted in few instances of underdialysis. We used URR \% (which is mandated by CMS) because many dialysis facilities do not routinely calculate $\mathrm{KT} / \mathrm{V}$ and the latter is intrinsically related to nPCR. A lack of association of weight loss (as indicated by changes in the post dialysis goal weight) with serum albumin levels $<3.8 \mathrm{~g} / \mathrm{dl}$ was seen due to an insufficient number of instances of weight loss during the study period; however, there was a correlation between such goal weight changes and mean serum albumin (Tables $2 \& 4$ ). Dry weight is determined by nephrologists by clinical trial and error with the attendant pitfalls when used for analysis. We did not find an association between baseline dry weight and albumin or inflammatory markers [56,57]. We did not analyze inter-dialytic weight gain vs. albumin change in our study; others have observed a negative effect of lower interdialytic

Table 4 Results of multiple linear regression: effect of risk factors on mean serum albumin

\begin{tabular}{|c|c|c|c|c|}
\hline Model & Standardized Coefficient & $95 \% \mathrm{Cl}$ & $95 \% \mathrm{Cl}$ & 2-tailed $p$ \\
\hline & (Beta) & Lower & Upper & \\
\hline (Constant) & 3.277 & 2.713 & 3.728 & $0.001 *$ \\
\hline $\mathrm{nPCR}$ & 0.180 & 0.063 & 0.415 & $0.010 *$ \\
\hline URR\% (Mean) & 0.048 & -0.003 & 0.010 & 0.413 \\
\hline Ferritin (ng/ml) & -0.038 & -5.197 & 0.000 & 0.395 \\
\hline Phosphate (mg/dl) & 0.043 & -0.011 & 0.033 & 0.376 \\
\hline $\mathrm{WBC} \times 1000 / \mathrm{cmm}$ & -0.044 & -0.024 & 0.009 & 0.372 \\
\hline Weight change\% & 0.043 & -0.006 & 0.012 & 0.458 \\
\hline Fever & 0.097 & -0.013 & 0.138 & $0.036 *$ \\
\hline Days in Hospital & -0.301 & -0.022 & -0.007 & $0.001 *$ \\
\hline Bacteremia Episodes & -0.179 & -0.286 & -0.035 & $0.005 *$ \\
\hline Vintage (months) & -0.100 & -0.002 & -5.187 & $0.035 *$ \\
\hline Male Gender & 0.105 & 0.005 & 0.146 & $0.044 *$ \\
\hline Diabetes mellitus & -0.163 & -0.185 & -0.046 & $0.004 *$ \\
\hline Age in years & -0.175 & -0.006 & -0.002 & $0.001 *$ \\
\hline
\end{tabular}

* Significant. 
Table 5 Results of binary logistic regression: serum albumin $<3.8$ vs. risk factors

\begin{tabular}{|c|c|c|c|c|c|}
\hline & & $95 \%$ & $\mathrm{Cl}$ & & \\
\hline Factor & $L R(\exp B)$ & Lower & Upper & $p$ & $p$ (with bootstrapping) \\
\hline Age in years & 1.029 & 1.000 & 1.059 & $0.051 *$ & $0.008 *$ \\
\hline Female Sex & 3.684 & 1.566 & 8.667 & $0.003 *$ & $0.001 *$ \\
\hline Diabetes mellitus & 0.137 & 0.049 & 0.381 & $<0.001 *$ & $0.001 *$ \\
\hline Vintage (months) & 0.992 & 0.982 & 1.002 & 0.103 & 0.057 \\
\hline$\% \cup R R$ & 1.006 & 0.927 & 1.092 & 0.878 & 0.870 \\
\hline $\mathrm{nPCR}$ & 0.232 & 0.051 & 1.045 & 0.057 & $0.043 *$ \\
\hline Serum Phosphate & 0.912 & 0.689 & 1.208 & 0.521 & 0.447 \\
\hline \%Weight Loss & 1.082 & 0.980 & 1.194 & 0.119 & 0.128 \\
\hline Days in Hospital & 1.042 & 0.926 & 1.174 & 0.492 & 0.470 \\
\hline Febrile Episodes & 1.502 & 0.413 & 5.456 & 0.537 & 0.501 \\
\hline Bacteremia & 0.982 & 0.248 & 3.891 & 0.979 & 0.962 \\
\hline Leukocytosis & 0.955 & 0.766 & 1.190 & 0.682 & 0.696 \\
\hline Serum Ferritin & 0.999 & 0.997 & 1.000 & 0.064 & $0.047 *$ \\
\hline
\end{tabular}

* = significant. LR = Likelihood Ratio. Bootstrapping performed with 1000 iterations.

weight gain on nPCR, prealbumin, and dry weight in longitudinal analyses [57]. Dialysis vintage is associated with a higher relative risk of death in case-mix adjusted analyses independent of nutritional and other variables in larger cohorts [58]. Vintage appeared to be associated with albu$\min <3.8 \mathrm{~g} / \mathrm{dl}$ in our patients only by univariate methods, and was of borderline significance in multivariate analyses, but did not correlate with mean serum albumin. Inflammation and dietary protein intake are known to impact serum albumin in opposing ways [59]. One effect of the chronic inflammatory state in dialysis patients is sustained hypoalbuminemia according to the HEMO Study [60]. Serum ferritin is measured routinely in most U.S dialysis units to guide intravenous iron therapy, and is a surrogate for inflammation that associates with short term mortality and hypoalbuminemia [61]; it appeared to correlate with albumin $<3.8 \mathrm{~g} / \mathrm{dl}$ in our study. Hospitalization is associated with malnutrition in general, and protein malnutrition in particular, even in well dialyzed patients $[53,62]$ and correlates with weight loss, reduction in albumin, and inflammation, particularly when the stay is prolonged and caused by inflammatory conditions [63]; we did not find a correlation of hospital stay with albumin $<3.8 \mathrm{~g} / \mathrm{dl}$ but it was negatively associated with mean albumin levels. The bromocresol purple method of albumin measurement which gives slightly lower levels is closer to the gold standard of immunonephelometry and may provide value to our data $[64,65]$.

\section{Limitations of the study}

This was a retrospective analysis of patient data with the attendant pitfalls. Residual renal function (which can lower nPCR) was not studied because there were only a few patients who were not oliguric and 24 hour urine determinations were not available. Such residual function would likely inflate, not diminish, the impact of nPCR on albumin. We were not able to demonstrate any longitudinal pattern of variation in the albumin levels relative to nPCR of any given month. Also, observation of the data suggested a relatively small number of instances of hospital stay and positive blood culture; this could have diminished the demonstrated impact of inflammation. C-reactive protein and pre-albumin levels would have provided valuable information and were not available and are not generally measured in U.S dialysis units routinely.

\section{Conclusions}

Protein intake as measured by nPCR correlates with serum albumin even when confounding factors are taken into account. Prospective studies are required to confirm whether albumin targets would be difficult to achieve in elderly female diabetics and whether protein supplementation would alter albumin levels in such vulnerable subgroups.

\section{Competing interests}

The authors declare that they have no competing interests.

\section{Authors' contributions}

NS conceived of and planned the study, performed statistical analyses, prepared tables and graphs, wrote the abstract and manuscript, mentored SJ in collation of data, and corresponded with the publisher. SJ collected and collated the data, obtained informed consent from patients for inclusion of their data, obtained Institutional Review Board approval, compiled and assigned references quoted in the paper. Both authors read and approved the final manuscript.

\section{Acknowledgements}

The authors thank the staff of The Buffalo General Hospital Dialysis Unit for the co-operation extended to $\mathrm{S} J$ in obtaining data and interacting with patients while obtaining consent. We also thank Christina Chelus, RD, for sharing data with $\mathrm{SJ}$. 


\section{Author details}

'Department of Internal Medicine (Nephrology), Buffalo General Hospital, University at Buffalo, and Buffalo Medical Group, 85 High Street, Buffalo, New York, USA. ${ }^{2}$ Research Associate, Kaleida Health (Buffalo General Hospital) 2009. Visiting Observer, Internal Medicine 2008-9, 411, 5th Floor, Kancharla Towers, Golconda X Roads, 500020, Hyderabad, India.

Received: 16 June 2012 Accepted: 23 October 2013

Published: 1 November 2013

\section{References}

1. United States Renal Data System: 2010 Statisitics. downloaded September 25th. ; 2011. www.usrds.org

2. Held PJ, et al:: Excerpts from United States Renal Data System 1997 Annual Data Report. American journal of kidney diseases : the official journal of the National Kidney Foundation 1997, 30:S1-S213. Epub 1997/08/01.

3. Acchiardo SR, Moore LW, Latour PA: Malnutrition as the main factor in morbidity and mortality of hemodialysis patients. Kidney Int Supp/ 1983, 16(6429404):199-203.

4. Kopple JD: McCollum Award Lecture, 1996: protein-energy malnutrition in maintenance dialysis patients. Am J Clin Nutr 1997, 65(9129491):1544-1557.

5. Kalantar-Zadeh K, Kopple JD: Relative contributions of nutrition and inflammation to clinical outcome in dialysis patients. Am J Kidney Dis 2001, 38(6):1343-1350.

6. Kalantar-Zadeh K, Kopple JD, Block G, Humphreys MH: A malnutrition-inflammation score is correlated with morbidity and mortality in maintenance hemodialysis patients. Am J Kidney Dis 2001, 38(6):1251-1263.

7. Stenvinkel P, Heimbürger O, Paultre F, Diczfalusy U, Wang T, Berglund L, Jogestrand T: Strong association between malnutrition, inflammation, and atherosclerosis in chronic renal failure. Kidney international 1999, 55(5):1899-1911

8. Herselman M, Esau N, Kruger JM, Labadarios D, Moosa MR: Relationship between serum protein and mortality in adults on long-term hemodialysis: exhaustive review and meta-analysis. Nutrition 2010, 26(1):10-32

9. Pifer TB, Mccullough KP, Port FK, Goodkin DA, Maroni BJ, Held PJ, Young EW: Mortality risk in hemodialysis patients and changes in nutritional indicators: DOPPS. Kidney international 2002, 62(6):2238-2245.

10. Combe C, McCullough KP, Asano Y, Ginsberg N, Maroni BJ, Pifer TB: Kidney disease outcomes quality initiative (K/DOQI) and the dialysis outcomes and practice patterns study (DOPPS): nutrition guidelines, indicators, and practices. Am J Kidney Dis 2004, 44:39-46.

11. Honda H, Qureshi AR, Heimbürger O, Barany P, Wang K, Pecoits-Filho R, Stenvinkel $P$, Lindholm B: Serum albumin, C-reactive protein, interleukin 6 , and fetuin a as predictors of malnutrition, cardiovascular disease, and mortality in patients with ESRD. Am J Kidney Dis 2006, 47(1):139-148.

12. Kalantar-Zadeh K, Kilpatrick RD, Kuwae N, McAllister CJ, Alcorn H, Kopple JD, Greenland S: Revisiting mortality predictability of serum albumin in the dialysis population: time dependency, longitudinal changes and population-attributable fraction. Nephrol Dial Transplant 2005, 20(9):1880.

13. Goldwasser P, Feldman J: Association of serum albumin and mortality risk. Journal of clinical epidemiology 1997, 50(6):693-703.

14. TG T: report to Congress on medical nutrition therapy. Washington, DC: Department of Health and Human Services; 2004.

15. Friedman AN, Fadem SZ: Reassessment of albumin as a nutritional marker in kidney disease. J Am Soc Nephrol 2010, 21(2):223-230.

16. Capelli JP, Kushner H, Camiscioli TC, Chen SM, Torres MA: Effect of intradialytic parenteral nutrition on mortality rates in end-stage renal disease care. American journal of kidney diseases: the official journal of the National Kidney Foundation 1994, 23(6):808.

17. Mehrotra R, Duong U, Jiwakanon S, Kovesdy CP, Moran J, Kopple JD, Kalantar-Zadeh K: Serum albumin as a predictor of mortality in peritoneal dialysis: Comparisons with hemodialysis. Am J Kidney Dis 2011, 58(3):418-428.

18. Rocco MV, Frankenfield DL, Hopson SD, McClellan WM: Relationship between clinical performance measures and outcomes among patients receiving long-term hemodialysis. Annals of internal medicine 2006 145(7):512-519.

19. Centers for Medicare and Medicaid Services: 2008 Annual Report. End Stage Renal Disease Clinical performance Measures Project. Baltimore, MD:
Department of Health and Human services, Office of clinical standards and quality; 2008.

20. Fouque D, Kalantar-Zadeh K, Kopple J, Cano N, Chauveau P, Cuppari L, Franch H, Guarnieri G, Ikizler T, Kaysen G: A proposed nomenclature and diagnostic criteria for protein-energy wasting in acute and chronic kidney disease. Kidney international 2007, 73(4):391-398.

21. Avram MM, Sreedhara R, Fein P, Oo KK, Chattopadhyay J, Mittman N: Survival on hemodialysis and peritoneal dialysis over 12 years with emphasis on nutritional parameters. Am J Kidney Dis 2001, 37(1):S77-S80.

22. Kaysen GA, Dubin JA, Müller HG, Mitch WE, Rosales LM, Levin NW: Relationships among inflammation nutrition and physiologic mechanisms establishing albumin levels in hemodialysis patients. Kidney international 2002, 61(6):2240-2249.

23. NAKAMOTO H, HONDA N, MIMURA T, SUZUKI H: Hypoalbuminemia is an important risk factor of hypotension during hemodialysis. Hemodial Int 2006, 10(S2):S10-S15.

24. Moon KH, Song IS, Yang WS, Shin YT, Kim SB, Song JK, Park JS: Hypoalbuminemia as a risk factor for progressive left-ventricular hypertrophy in hemodialysis patients. American journal of nephrology 2000, 20(5):396-401.

25. Mistrík E, Dusilová-Sulková S, Bláha V, Sobotka L: Plasma albumin levels correlate with decreased microcirculation and the development of skin defects in hemodialyzed patients. Nutrition 2010, 26(9):880-885.

26. Don BR, Kaysen G: Poor Nutritional Status and Inflammation: Serum Albumin: Relationship to Inflammation and Nutrition. 2004. www.onlinelibrary.wiley.com.

27. Kaysen GA: Biological basis of hypoalbuminemia in ESRD. J Am Soc Nephrol 1998, 9(12):2368-2376.

28. Thijssen S, Wystrychowski G, Usvyat L, Kotanko P, Levin NW: Determinants of serum albumin concentration analyzed in a large cohort of patients on maintenance hemodialysis. Journal of renal nutrition 2007, 17(1):70-74

29. Qureshi AR, Alvestrand A, Danielsson A, Divino-Filho JC, Gutierrez A, Lindholm B, Bergström J: Factors predicting malnutrition in hemodialysis patients: a cross-sectional study. Kidney international 1998, 53(3):773-782.

30. Kıyıcı A, Mehmetoğlu I, Karaoğlan H, Atalay H, Solak Y, Türk S: Ischemia-Modified albumin levels in patients with end-stage renal disease patients on hemodialysis: does albumin analysis method affect albumin-adjusted Ischemia-Modified albumin levels? Journal of clinical laboratory analysis 2010, 24(4):273-277.

31. Terawaki H, Takada $Y$, Era S, Funakoshi $Y$, Nakayama K, Nakayama M, Ogura M, Ito S, Hosoya T: The redox state of albumin and serious cardiovascular incidence in hemodialysis patients. Ther Apher Dial 2010, 14(5):465-471.

32. Wratten $M L$, Sereni $L$, Tetta C: Hemolipodialysis attenuates oxidative stress and removes hydrophobic toxins. Artificial organs 2000, 24(9):685-690.

33. Himmelfarb J, McMonagle E: Albumin is the major plasma protein target of oxidant stress in uremia. Kidney international 2001, 60(1):358-363.

34. Pavone B, Sirolli V, Bucci S, Libardi F, Felaco P, Amoroso L, Sacchetta P, Urbani A, Bonomini M: Adsorption and carbonylation of plasma proteins by dialyser membrane material: in vitro and in vivo proteomics investigations. Blood Transfus 2010, 8(Suppl 3):s113.

35. Soejima A, Matsuzawa N, Miyake N, Karube M, Fukuoka K, Nakabayashi K, Kitamoto K, Nagasawa T: Hypoalbuminemia accelerates erythrocyte membrane lipid peroxidation in chronic hemodialysis patients. Clinical nephrology 1999, 51(2):92.

36. Mera K, Anraku M, Kitamura K, Nakajou K, Maruyama T, Otagiri M: The structure and function of oxidized albumin in hemodialysis patients: Its role in elevated oxidative stress via neutrophil burst. Biochemical and biophysical research communications 2005, 334(4):1322-1328.

37. Sezer MT, Akin H, Demir M, Erturk J, Aydin ZD, Savik E, Tunc N: The effect of serum albumin level on iron-induced oxidative stress in chronic renal failure patients. Journal of nephrology 2007, 20(2):196.

38. Leavey SF, Strawderman RL, Young EW, Saran R, Roys E, Agodoa LYC, Wolfe RA, Port FK: Cross-sectional and longitudinal predictors of serum albumin in hemodialysis patients. Kidney international 2000, 58(5):2119-2128

39. Burrowes JD, Cockram DB, Dwyer JT, Larive B, Paranandi L, Bergen C, Poole D: Cross-sectional relationship between dietary protein and energy intake, nutritional status, functional status, and comorbidity in older versus younger hemodialysis patients. Journal of renal nutrition 2002, 12(2):87-95 
40. Cupisti A, D’Alessandro C, Valeri A, Capitanini A, Meola M, Betti G, Barsotti G: Food intake and nutritional status in stable hemodialysis patients. Ren Fail 2010, 32(1):47-54.

41. Bossola M, Muscaritoli M, Tazza L, Panocchia N, Liberatori M, Giungi S, Tortorelli A: Variables associated with reduced dietary intake in hemodialysis patients. Journal of renal nutrition 2005, 15(2):244-252.

42. Maggiore Q, Nigrelli S, Ciccarelli C, Grimaldi C, Rossi GA, Michelassi C: Nutritional and prognostic correlates of bioimpedance indexes in hemodialysis patients. Kidney international 1996, 50(6):2103.

43. Aparicio M, Cano N, Chauveau P, Azar R, Canaud B, Flory A, Laville M, Leverve $X$ : Nutritional status of haemodialysis patients: a French national cooperative study. French Study Group for Nutrition in Dialysis. Nephrol Dial Transplant 1999, 14(7):1679.

44. Juarez-Congelosi M, Orellana P, Goldstein SL: Normalized protein catabolic rate versus serum albumin as a nutrition status marker in pediatric patients receiving hemodialysis. Journal of renal nutrition 2007, 17(4):269-274.

45. Kaysen GA, Greene T, Daugirdas JT, Kimmel PL, Schulman GW, Toto RD, Levin NW, Yan G: Longitudinal and cross-sectional effects of C-reactive protein, equilibrated normalized protein catabolic rate, and serum bicarbonate on creatinine and albumin levels in dialysis patients. Am J Kidney Dis 2003, 42(6):1200-1211.

46. Rao M, Sharma M, Juneja R, Jacob S, Jacob CK: Calculated nitrogen balance in hemodialysis patients: influence of protein intake. Kidney international 2000, 58(1):336-345.

47. Klahr S, Levey AS, Beck GJ, Caggiula AW, Hunsicker L, Kusek JW, Striker G: The effects of dietary protein restriction and blood-pressure control on the progression of chronic renal disease. N Engl J Med 1994, 330(13):877-884

48. Kaysen GA, Johansen KL, Cheng SC, Jin C, Chertow GM: Trends and outcomes associated with serum albumin concentration among incident dialysis patients in the United States. Journal of renal nutrition 2008, 18(4):323-331.

49. De Mutsert R, Grootendorst DC, Indemans F, Boeschoten EW, Krediet RT, Dekker FW: Association between serum albumin and mortality in dialysis patients is partly explained by inflammation, and not by malnutrition. Journal of renal nutrition 2009, 19(2):127-135.

50. Greene SV, Falciglia G, Rademacher R: Relationship between serum phosphorus levels and various outcome measures in adult hemodialysis patients. Journal of renal nutrition 1998, 8(2):77-82.

51. Combe C, Chauveau P, Laville M, Fouque D, Azar R, Cano N, Canaud B, Roth $H$, Leverve $X$, Aparicio M: Influence of nutritional factors and hemodialysis adequacy on the survival of 1,610 French patients. Am J Kidney Dis 2001, 37(1):S81-S88

52. Kalantar-Zadeh K, Supasyndh O, Lehn RS, McAllister CJ, Kopple JD: Normalized protein nitrogen appearance is correlated with hospitalization and mortality in hemodialysis patients with $\mathrm{Kt} / \mathrm{V}$ greater than 1.20. Journal of renal nutrition 2003, 13(1):15-25.

53. Noori N, Kalantar-Zadeh K, Kovesdy CP, Bross R, Benner D, Kopple JD: Association of dietary phosphorus intake and phosphorus to protein ratio with mortality in hemodialysis patients. Clin J Am Soc Nephrol 2010, 5(4):683-692.

54. Zitt E, Lamina C, Sturm G, Knoll F, Lins F, Freistatter O, Kronenberg F, Lhotta $\mathrm{K}$, Neyer $\mathrm{U}$ : Interaction of time-varying albumin and phosphorus on mortality in incident dialysis patients. Clin J Am Soc Nephrol 2011, 6(11):2650-2656.

55. Lynch KE, Lynch R, Curhan GC, Brunelli SM: Prescribed dietary phosphate restriction and survival among hemodialysis patients. Clin J Am SOC Nephrol 2011, 6(3):620-629.

56. Torun D, Micozkadioglu H, Torun N, Ozelsancak R, Sezer S, Adam FU, Ozdemir FN, Haberal M: Increased body mass index is not a reliable marker of good nutrition in hemodialysis patients. Ren Fail 2007, 29(4):487-493.

57. Sezer S, Nurhan Özdemir F, Arat Z, Perim Ö, Turan M, Haberal M: The association of interdialytic weight gain with nutritional parameters and mortality risk in hemodialysis patients. Ren Fail 2002, 24(1):37-48.

58. Chertow GM, Johansen KL, Lew N, Lazarus JM, Lowrie EG: Vintage, nutritional status, and survival in hemodialysis patients. Kidney international 2000, 57(3):1176-1181.

59. Kaysen GA, Chertow GM, Adhikarla R, Young B, Ronco C, Levin NW: Inflammation and dietary protein intake exert competing effects on serum albumin and creatinine in hemodialysis patients Kidney international 2001, 60(1):333-340.

60. Kaysen GA, Dubin JA, Müller HG, Rosales LM, Levin NW: The acute-phase response varies with time and predicts serum albumin levels in hemodialysis patients. Kidney international 2000, 58(1):346-352.

61. Kalantar-Zadeh K, Don BR, Rodriguez RA, Humphreys MH: Serum ferritin is a marker of morbidity of mortality in hemodialysis patients. Am J Kidney Dis 2001, 37(3):564-572.

62. Ikizler TA, Greene JH, Yenicesu M, Schulman G, Wingard RL, Hakim RM: Nitrogen balance in hospitalized chronic hemodialysis patients. Kidney international Supplement 1996, 57:S53.

63. Borrego UFJ, Segura TP, Pérez DBMP, Serrano AP, Sánchez PMC, García CMJ, Pérez BV: Loss of weight in hemodialysis patients after hospitalization is related with length of stay and degree of inflammation]. Nefrología: publicación oficial de la Sociedad Española Nefrologia 2010, 30(5):557.

64. Carfray A, Patel K, Whitaker P, Garrick P, Griffiths GJ, Warwick GL: Albumin as an outcome measure in haemodialysis in patients: the effect of variation in assay method. Nephrol Dial Transplant 2000, 15(11):1819.

65. Clase CM, St Pierre MW, Churchill DN: Conversion between bromcreso green-and bromcresol purple-measured albumin in renal disease. Nephrol Dial Transplant 2001, 16(9):1925.

doi:10.1186/1471-2369-14-242

Cite this article as: Sridhar and Josyula: Hypoalbuminemia in

hemodialyzed end stage renal disease patients: risk factors and relationships - a 2 year single center study. BMC Nephrology 2013 14:242.

\section{Submit your next manuscript to BioMed Central and take full advantage of:}

- Convenient online submission

- Thorough peer review

- No space constraints or color figure charges

- Immediate publication on acceptance

- Inclusion in PubMed, CAS, Scopus and Google Scholar

- Research which is freely available for redistribution

Submit your manuscript at www.biomedcentral.com/submit
C) Biomed Central 